\title{
Self-renewal versus transformation: Fbxw7 deletion leads to stem cell activation and leukemogenesis
}

\author{
John M. Perry ${ }^{1}$ and Linheng $\mathrm{Li}^{1,2,3}$ \\ ${ }^{1}$ Stowers Institute for Medical Research, Kansas City, Missouri 64110, USA; ${ }^{2}$ Department of Pathology, Kansas University \\ Medical Center, Kansas City, Kansas 66160, USA
}

\begin{abstract}
Recent reports have demonstrated that specific tumor suppressors are important for both maintaining hematopoietic stem cell (HSC) quiescence and preventing leukemia development, suggesting a connection between these two activities. Matsuoka and colleagues (pp. 986991) have further illustrated this theme by demonstrating that inactivation of the tumor suppressor $\mathrm{Fbxw} 7$ leads to HSC depletion by active cell cycling and the initiation of leukemia.
\end{abstract}

Adult hematopoietic stem cells (HSCs) are believed to be relatively quiescent, contributing to blood homeostasis throughout an organism's life span. Aberrant, overactive cycling of HSCs can lead to exhaustion of the stem cell pool and blood cell depletion or leukemia development. Significantly, numerous tumor suppressors and protooncogenes have been implicated in the regulation of HSC self-renewal, including PTEN, Bmi-1, Notch, c-Myc, JunB, and MEF/ELF4 (Calvi et al. 2003; Park et al. 2003; Passegue et al. 2004; Wilson et al. 2004; Lacorazza et al. 2006; Yilmaz et al. 2006; Zhang et al. 2006; Hosen et al. 2007). In the previous issue of Genes \& Development, Matsuoka et al. (2008) demonstrate a role for the tumor suppressor Fbxw7 in maintaining HSC quiescence and preventing leukemia formation.

First identified in Caenorhabditis elegans as a negative regulator of Notch, Fbxw7 is localized within the human 4q32 locus, which is frequently deleted in diverse cancers (Akhoondi et al. 2007). On average, 6\% of tumors exhibit mutation in Fbxw7; however, higher frequencies are observed in certain types of malignancy. For instance, Fbxw 7 is mutated in $\sim 30 \%$ of patients with T-cell acute lymphoblastic leukemia (T-ALL) but is rarely mutated in other types of leukemia. As a ubiquitin ligase, Fbxw 7 plays a key role in protein turnover by targeting specific proteins for proteosomal degradation. Aberrant protein degradation can contribute to tumor

[Keywords: Fbxw7; c-Myc; Notch1; p53; hematopoiesis; T-ALL] ${ }^{3}$ Corresponding author.

E-MAIL lil@stowers-institute.org; FAX (816) 926-2023.

Article is online at http://www.genesdev.org/cgi/doi/10.1101/gad.1670708. formation, as tumor suppressors may be targeted for rapid degradation while oncogenes may resist degradation in certain cancers (Welcker and Clurman 2008). Fbxw7 may be of particular interest in this regard because Fbxw7's substrates include several prominent proto-oncogenes including Notch, c-Myc, JunB, and cyclin E. As such, Fbxw7 has been identified as an important tumor suppressor with loss-of-function mutations leading to chromosomal instability (Perez-Losada et al. 2005; Nakayama and Nakayama 2006; Welcker and Clurman 2008).

By negatively regulating cyclin E, Fbxw7 plays a key role in cell cycle control. Cyclin $\mathrm{E}$ is involved in driving quiescent (G0) or G1 cells into $S$ phase and, predictably, is frequently dysregulated in cancer (Hwang and Clurman 2005). Notch is also negatively regulated by Fbxw7 and can serve as an oncogene in T-ALL, where $>50 \%$ of these malignancies exhibit activating mutations in Notch (Weng et al. 2004; Grabher et al. 2006). Notch is important for directing lymphoid lineage cell fate determination and has also been implicated in HSC self-renewal. In particular, Notch is expressed by HSCs while its ligand, Jagged, is expressed by the HSC niche, and increased Jagged/Notch activation results in increased HSC number and niche expansion (Calvi et al. 2003). Thus, Notch activity may increase both self-renewal capacity and T-cell lineage commitment, which may significantly contribute to T-ALL development. Interestingly, Fbxw7 seems to play a particularly prominent role in regulating the Notch pathway by targeting not only Notch itself but also several upstream and downstream components of the Notch pathway (Welcker and Clurman 2008). This includes the prominent proto-oncogene $\mathrm{c}-\mathrm{Myc}$, which is a direct Notch target and is often linked to Notch-associated leukemia (Weng et al. 2006).

These themes are illustrated in the current study by Matsuoka et al. (2008) Here, conditional deletion of Fbxw7 was examined in the hematopoietic system. Fbxw7 is expressed in most hematopoietic lineages including lineage marker-negative, $\mathrm{Sca}-1^{+}, \mathrm{Kit}^{+}$(LSK) cells, which are highly enriched in HSCs. The highest expression is observed in lymphoid lineages, especially CD4 ${ }^{+}$ $\mathrm{CD}^{+}$(double positive or DP) T lymphocytes. Although 
immature (lineage marker-negative) cells are reduced in Fbxw7-deficient mice, Fbxw7 appears to be dispensable for multilineage terminal differentiation. Regarding HSCs, the repopulating capability of mutants is severely impaired. A relatively quiescent HSC population, LSK CD34- cells, exhibited reduced frequency of cells in G0 in Fbxw7 mutants, suggesting that Fbxw7 may have a role in maintaining HSC quiescence. Although actively cycling, HSCs are not reported to accumulate in Fbxw7 mutants. Instead, HSCs eventually decline. Matsuoka et al. (2008) examined several well-known substrates of Fbxw7 including JunB, c-Myc, and Notch. No changes in JunB protein levels were observed in LSK CD34- cells; however, both Notch and c-Myc protein levels were substantially increased in Fbxw7-deficient LSK CD34- cells. Differential disease manifestation was observed in Fbxw7 mutants, with $\sim 30 \%$ exhibiting severe reduction in white blood cells (leukopenia) at $12 \mathrm{wk}$ post-induction due to p53-induced apoptosis. In contrast, Fbxw7-deficient mice that did not exhibit leukopenia have reduced levels of p53 and normal frequency of apoptotic cells. Correspondingly, most mice without leukopenia develop T-ALL with DP T lymphocytes predominating. In contrast, none with leukopenia develop leukemia. Given the 3- to 4-mo latency and differential manifestation of disease in Fbxw 7 mutants, additional mutations appear to be necessary for transformation, and p53 is a prime candidate for one such additional mutation. To confirm p53's potential role in suppressing leukemic transformation, p53-deficient/Fbxw7-deficient double mutant mice were examined. These double mutants exhibited both reduced leukopenia and much shorter disease latency. Thus, p53 appears to protect from oncogenic activity resulting from Fbxw7 deficiency. Leukemic transformation occurs only by selection of cells with suppressed p53.

These data correspond with clinical observations that Fbxw7 deficiency is frequently found in conjunction with loss of p53. Notably, Fbxw7 has been described as a p53-dependent tumor suppressor, having multiple putative p53-binding sites within its regulatory regions. Thus, Fbxw7 may be a p53-inducible gene (Mao et al. 2004). Interestingly, most natural Fbxw7 mutations in cancers are heterozygous but also exhibit p53 mutation.
Initially, p53 may suppress the consequences of Fbxw7 haploinsufficency; however, a second "hit" in p53 in cooperation with Fbxw7 deficiency may then lead to tumorigenesis. Indeed, p53 and Fbxw 7 have been shown to cooperatively restrain cyclin E-induced chromosomal instability (Minella et al. 2007).

With rare exception, stem cells are unique in having self-renewal capability, a potentially dangerous property if hijacked by tumor-initiating or cancer stem cells (Reya et al. 2001). Other reports have also recently illustrated a connection between tumor suppressor deficiency resulting in HSC activation coupled with malignant transformation, notably in PTEN-deficient mice (Yilmaz et al. 2006; Zhang et al. 2006). As with PTEN mutants, Fbxw7 mutant mice exhibit increased cell cycle activation in HSCs leading to HSC exhaustion. This highlights the importance of maintaining relative quiescence of HSCs, which is believed to be sustained by the HSC osteoblastic niche (Calvi et al. 2003; Zhang et al. 2003; Arai et al. 2004). PTEN deletion results in HSC mobilization to the spleen with transient, but unsustainable, expansion. However, Fbxw7-deficient HSCs were not reported to be increased even transiently. This is likely the result of p53-mediated apoptosis. In the case of PTEN deficiency, p53 may fail to prevent an increase in HSCs because PTEN is reported to regulate p53 stability; thus, PTEN loss may lead to reduction in p53 (Stambolic et al. 2001; Freeman et al. 2003; Trotman and Pandolfi 2003). In the Fbxw7-deficient model, loss of p53 and its apoptotic activity appears to be necessary for malignant transformation, with increased Notch leading to uncontrolled Tcell proliferation. Interestingly, c-Myc may play an additional role in HSC activation in Fbxw7 mutants. c-Myc has been reported to regulate the interaction between HSCs and the osteoblastic niche. This is based on studies showing that conditional deletion of c-Myc results in the accumulation of HSCs with up-regulation of niche-specific adhesion molecules such as $\mathrm{N}$-cadherin. Likewise, forced expression of c-Myc results in decreased $\mathrm{N}$-cadherin and release of HSCs from their niche (Wilson et al. 2004). Thus, increased c-Myc in Fbxw7-deficient mice may lead to the release of HSCs from their quiescencepromoting osteoblastic niche, which may promote aber-

Figure 1. Tumor suppessors and proto-oncogenes coordinately regulate HSC activation versus quiescence. HSCs are maintained in a relatively quiescent state within their niche, maintaining a delicate balance of specific tumor suppressor and proto-oncogene activity. Deficiency in specific tumor suppressors or increased activity of specific proto-oncogenes leads to HSC activation and increased cell cycle entry. HSC expansion may be inhibited by p53-mediated apoptosis or senescence. Loss of p53 activityeither by secondary mutation or the loss of p53 stabilizers such as PTEN-results in uncontrolled HSC expansion. Having self-renewal capacity coupled with mutations that result in chromosomal instability, this population initiates leukemia development.

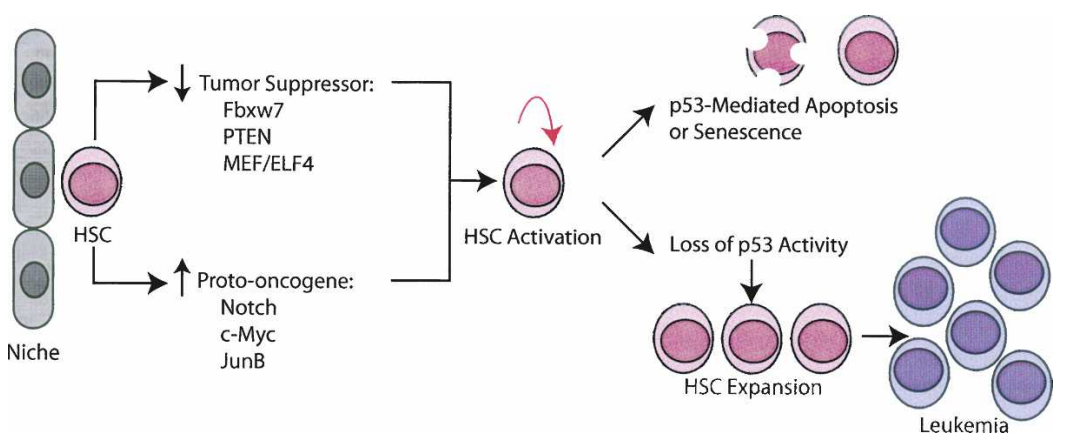


rant activation. However, further studies are necessary to test this.

Tumor suppressors appear to play a key role in regulating HSCs by strictly limiting their expansion and maintaining them as a rare population (Fig. 1). This normally prevents cancer stem cell development. Repression of potential oncogenic activity of HSCs by tumor suppressors such as Fbxw7 and PTEN may function by maintaining relative HSC quiescence and thus preventing HSC depletion. The role of the niche in this process merits further study. Loss of tumor suppressor activity results in HSC activation, which can be controlled by p53-mediated apoptosis or senescence. However, this aberrant activation leads to selection for p53-deficient cells, resulting in leukemogenesis. Similarly, proto-oncogenes such as c-Myc, Notch, and JunB have a role in governing HSC self-renewal and must be strictly limited to prevent leukemic transformation. Aberrant activation of proto-oncogenes, potentially via the loss of negative regulators such as Fbxw7, also leads to HSC activation, which sets the stage for leukemia development.

\section{References}

Akhoondi, S., Sun, D., von der Lehr, N., Apostolidou, S., Klotz, K., Maljukova, A., Cepeda, D., Fiegl, H., Dofou, D., Marth, C., et al. 2007. FBXW7/hCDC4 is a general tumor suppressor in human cancer. Cancer Res. 67: 9006-9012.

Arai, F., Hirao, A., Ohmura, M., Sato, H., Matsuoka, S., Takubo, K., Ito, K., Koh, G.Y., and Suda, T., 2004. Tie2/angiopoietin-1 signaling regulates hematopoietic stem cell quiescence in the bone marrow niche. Cell 118: 149-161.

Calvi, L.M., Adams, G.B., Weibrecht, K.W., Weber, J.M., Olson, D.P., Knight, M.C., Martin, R.P., Schipani, E., Divieti, P., Bringhurst, F.R., et al. 2003. Osteoblastic cells regulate the haematopoietic stem cell niche. Nature 425: 841-846.

Freeman, D.J., Li, A.G., Wei, G., Li, H.H., Kertesz, N., Lesche, R., Whale, A.D., Martinez-Diaz, H., Rozengurt, N., Cardiff, R.D., et al. 2003. PTEN tumor suppressor regulates p53 protein levels and activity through phosphatase-dependent and -independent mechanisms. Cancer Cell 3: 117-130.

Grabher, C., von Boehmer, H., and Look, A.T. 2006. Notch 1 activation in the molecular pathogenesis of T-cell acute lymphoblastic leukaemia. Nat. Rev. Cancer 6: 347-359.

Hosen, N., Yamane, T., Muijtjens, M., Pham, K., Clarke, M.F., and Weissman, I.L. 2007. Bmi-1-green fluorescent proteinknock-in mice reveal the dynamic regulation of Bmi-1 expression in normal and leukemic hematopoietic cells. Stem Cells 25: 1635-1644.

Hwang, H.C. and Clurman, B.E. 2005. Cyclin E in normal and neoplastic cell cycles. Oncogene 24: 2776-2786.

Lacorazza, H.D., Yamada, T., Liu, Y., Miyata, Y., Sivina, M., Nunes, J., and Nimer, S.D. 2006. The transcription factor $\mathrm{MEF} / \mathrm{ELF} 4$ regulates the quiescence of primitive hematopoietic cells. Cancer Cell 9: 175-187.

Mao, J.-H., Perez-Losada, J., Wu, D., DelRosario, R., Tsunematsu, R., Nakayama, K.I., Brown, K., Bryson, S., and Balmain, A. 2004. Fbxw7/Cdc4 is a p53-dependent, haploinsufficient tumour suppressor gene. Nature 432: 775-779.

Matsuoka, S., Oike, Y., Onoyama, I., Iwama, A., Arai, F., Takubo, K., Mashimo, Y., Oguro, H., Nitta, E., Ito, K., et al. 2008. Fbxw7 acts as a critical fail-safe against premature loss of hematopoietic stem cells and development of T-ALL.
Genes \& Dev. 22: 986-991.

Minella, A.C., Grim, J.E., Welcker, M., and Clurman, B.E. 2007. p53 and SCFFbw7 cooperatively restrain cyclin E-associated genome instability. Oncogene 26: 6948-6953.

Nakayama, K.I. and Nakayama, K. 2006. Ubiquitin ligases: Cellcycle control and cancer. Nat. Rev. Cancer 6: 369-381.

Park, I.K., Qian, D., Kiel, M., Becker, M.W., Pihalja, M., Weissman, I.L., Morrison, S.J., and Clarke, M.F. 2003. Bmi-1 is required for maintenance of adult self-renewing haematopoietic stem cells. Nature 423: 302-305.

Passegue, E., Wagner, E.F., and Weissman, I.L. 2004. JunB deficiency leads to a myeloproliferative disorder arising from hematopoietic stem cells. Cell 119: 431-443.

Perez-Losada, J., Mao, J.-H., and Balmain, A. 2005. Control of genomic instability and epithelial tumor development by the p53-Fbxw7/Cdc4 pathway. Cancer Res. 65: 6488-6492.

Reya, T., Morrison, S.J., Clarke, M.F., and Weissman, I.L. 2001. Stem cells, cancer, and cancer stem cells. Nature 414: 105111.

Stambolic, V., MacPherson, D., Sas, D., Lin, Y., Snow, B., Jang, Y., Benchimol, S., and Mak, T.W., 2001. Regulation of PTEN transcription by p53. Mol. Cell 8: 317-825.

Trotman, L.C., and Pandolfi, P.P., 2003. PTEN and p53: Who will get the upper hand? Cancer Cell 3: 97-99.

Welcker, M. and Clurman, B.E. 2008. FBW7 ubiquitin ligase: A tumour suppressor at the crossroads of cell division, growth and differentiation. Nat. Rev. Cancer 8: 83-93.

Weng, A.P., Ferrando, A.A., Lee, W., Morris, J.P.I.V., Silverman, L.B., Sanchez-Irizarry, C., Blacklow, S.C., Look, A.T., and Aster, J.C. 2004. Activating mutations of NOTCH1 in human T cell acute lymphoblastic leukemia. Science 306: 269 271.

Weng, A.P., Millholland, J.M., Yashiro-Ohtani, Y., Arcangeli, M.L., Lau, A., Wai, C., del Bianco, C., Rodriguez, C.G., Sai, H., Tobias, J., et al. 2006. c-Myc is an important direct target of Notch1 in T-cell acute lymphoblastic leukemia/lymphoma. Genes \& Dev. 20: 2096-2109.

Wilson, A., Murphy, M.J., Oskarsson, T., Kaloulis, K., Bettess, M.D., Oser, G.M., Pasche, A.C., Knabenhans, C., Macdonald, H.R., and Trumpp, A. 2004. c-Myc controls the balance between hematopoietic stem cell self-renewal and differentiation. Genes \& Dev. 18: 2747-2763.

Yilmaz, O.H., Valdez, R., Theisen, B.K., Guo, W., Ferguson, D.O., Wu, H., and Morrison, S.J. 2006. Pten dependence distinguishes haematopoietic stem cells from leukaemia-initiating cells. Nature 441: 475-482.

Zhang, J., Niu, C., Ye, L., Huang, H., He, X., Tong, W.G., Ross, J., Haug, J., Johnson, T., Feng, J.Q., et al. 2003. Identification of the haematopoietic stem cell niche and control of the niche size. Nature 425: 836-841.

Zhang, J., Grindley, J.C., Yin, T., Jayasinghe, S., He, X.C., Ross, J.T., Haug, J.S., Rupp, D., Porter-Westpfahl, K.S., Wiedemann, L.M., et al. 2006. PTEN maintains haematopoietic stem cells and acts in lineage choice and leukaemia prevention. Nature 441: 518-522. 


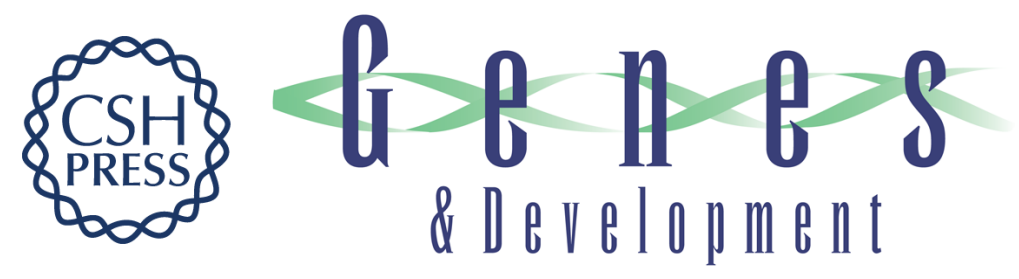

\section{Self-renewal versus transformation: Fbxw7 deletion leads to stem cell activation and leukemogenesis}

John M. Perry and Linheng Li

Genes Dev. 2008, 22:

Access the most recent version at doi:10.1101/gad.1670708
Related Content Fbxw7 acts as a critical fail-safe against premature loss of hematopoietic stem cells and development of T-ALL
Sahoko Matsuoka, Yuichi Oike, Ichiro Onoyama, et al.
Genes Dev. April , 2008 22: 986-991
References This article cites 25 articles, 6 of which can be accessed free at:
http://genesdev.cshlp.org/content/22/9/1107.full.html\#ref-list-1
Articles cited in:
http://genesdev.cshlp.org/content/22/9/1107.full.html\#related-urls

\section{License}
Email Alerting
Service
Receive free email alerts when new articles cite this article - sign up in the box at the top right corner of the article or click here.

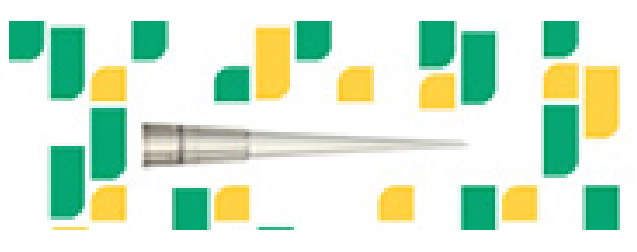

Focused on your science. 